Law, Development \& Justice Review

\begin{tabular}{llrr}
\hline \hline Volume: & 3 & E-ISSN: & $2655-1942$ \\
Number: & 1 & Terbitan: & Mei 2020 \\
Page : & $84-98$ & & \\
\hline
\end{tabular}

\title{
Konflik Kekuatan Hukum (Daya Mengikat) antara Akta Perdamaian dengan Putusan Mahkamah Agung
}

Ery Agus Priyono, Slamet Hariyono, Andi Sunarto, Kornelius Benuf

Fakultas Hukum, Universitas Diponegoro

Email: eryap@live.undip.ac.id

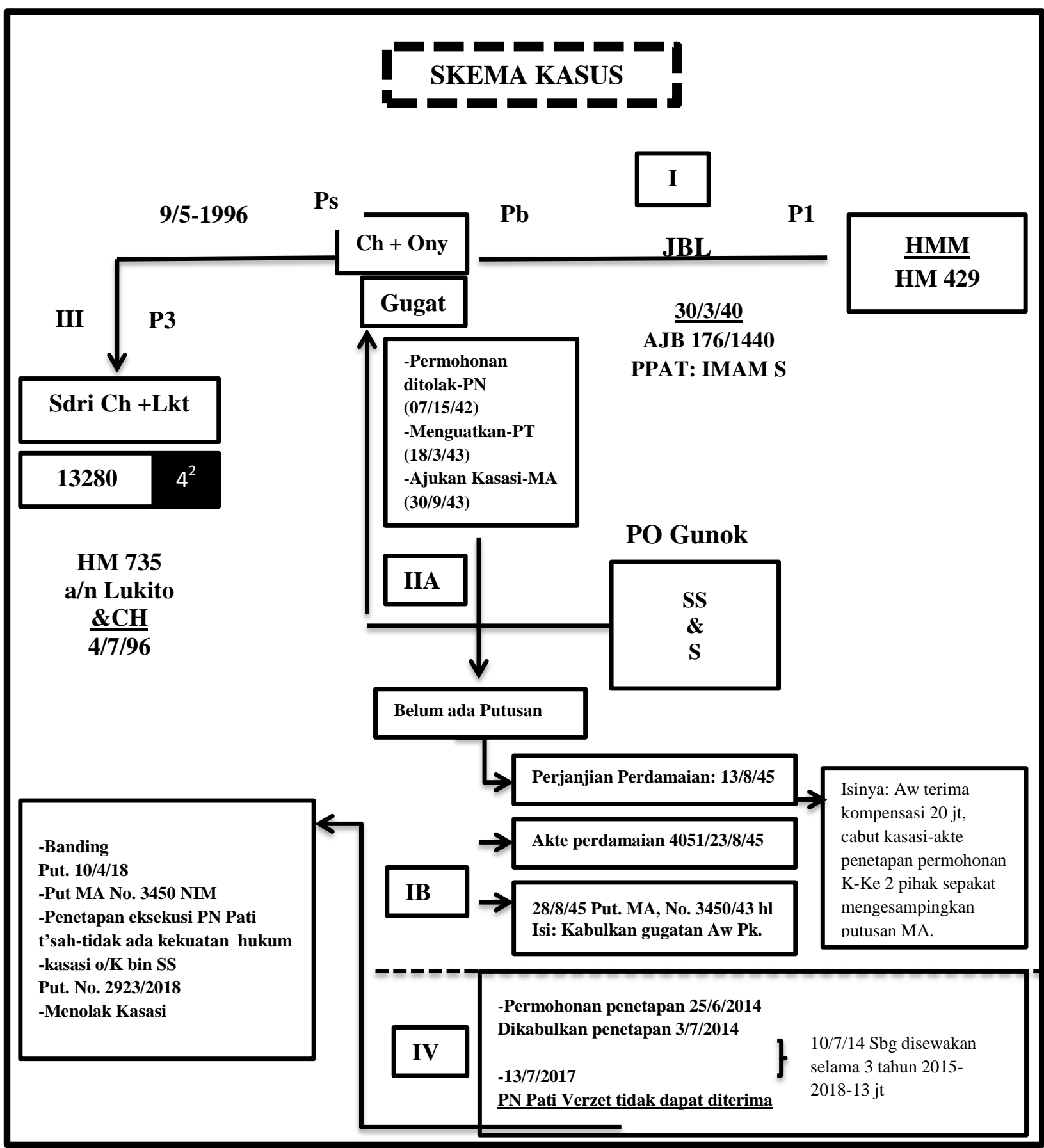




$\begin{array}{llrr}\text { Volume: } & 3 & \text { E-ISSN: } & 2655-1942 \\ \text { Number: } & 1 & \text { Terbitan: } & \text { Mei } 2020 \\ \text { Page : } & 84-98 & & \end{array}$

\section{[ URAIAN KASUS
I}

Adanya laporan dari $\mathrm{Ch}+\mathrm{LWD}$ tentang dugaan terjadinya tindak pidana penggelapan benda tidak bergerak berupa tanah seluas $13.280 \mathrm{M}^{2}$, sebagaimana terdaftar dalam Sertipikat HM No. XXX Ds. XX Kab. X a.n. LWD dan Ch, yang diduga dilakukan oleh Sdr. K bin SS. Adapun kronologis peristiwa tersebut adalah sebagai berikut:

- Bahwa Ch merupakan pemilik tanah seluas $13.280 \mathrm{M}^{2}$ yang terletak di Ds. Bumirejo Kec. Margorejo Kab. Pati dengan bukti kepemilikan berupa Sertipikat HM No. 735 Ds. Bumirejo Kec. Margorejo Kab. Pati a.n. LWD dan Ch. Tanah tersebut awalnya dibeli oleh Ch dan Ony dari H. MM pada tanggal 30 Maret 1990 dengan bukti berupa Akta Jual Beli nomor : XX, tanggal 30 Maret 1990 yang diterbitkan oleh PPAT IS dan pada saat terjadi jual beli, tanah tersebut masih terdaftar dalam sertipikat HM No. 429, karena terhadap tanah tersebut terbit sertipikat pertama kali pada tanggal 28 Agustus 1989 dengan HM nomor 429 atas nama H. MM. Selanjutnya pada tanggal 09 Mei 1996 terjadi jual beli kembali atas objek tanah tersebut dari Ony dan Ch kepada LWD dan Ch sendiri dengan bukti berupa Akta Jual Beli nomor xxx, tanggal 09 Mei 1996. Setelah adanya jual beli tersebut maka terbit Sertipikat pengganti atas tanah tersebut dari HM 429 menjadi HM 735 pada tanggal 04 Juli 1996.

- Sebelumnya pada tanggal 03 Juli 1991 terhadap sebagian objek tanah tersebut telah dilakukan gugatan perdata oleh SS dan S selaku ahli waris dari PK yang mengaku sebagai pemilik sebagian objek tanah tersebut. Sehingga terbit putusan perdata dari PN Pati nomor 46/Pdt.C/1991/PN.Pt. tanggal 07 Mei 1992, dengan isi putusan gugatan dari ahli waris PoK tersebut ditolak untuk seluruhnya. Atas putusan PN Pati tersebut pihak ahli waris PoK mengajukan banding sehingga terbit Putusan Pengadialan Tinggi Jawa Tengah nomor : XXX. Tanggal 18 Maret 1993, dengan isi putusan menguatkan putusan dari Pengadilan negeri Pati. Terhadap putusan tersebut pihak ahli waris PoK mengajukan Kasasi pada tanggal 30 September 1993

- Namun sebelum terbitnya putusan kasasi tersebut, kedua belah pihak sepakat mengadakan perdamaian sebagaimana Surat Perjanjian tertanggal 13 Agustus 1995 yang dikuatkan dengan 


$\begin{array}{llrr}\text { Volume: } & 3 & \text { E-ISSN: } & \text { 2655-1942 } \\ \text { Number: } & 1 & \text { Terbitan: } & \text { Mei 2020 } \\ \text { Page : } & 84-98 & & \end{array}$

Akta Perdamaian nomor 51 tanggal 23 Agustus 1995 yang dibuat oleh Notaris IS. Yang mana isi dari perdamian tersebut menyatakan bahwa ahli waris PoK menerima kompensasi dari. Ch, dkk sebesar Rp. 20.000.000,- (dua puluh juta rupiah) dan mencabut permohonan kasasi yang telah diajukan, kemudian apabila dikemudian hari terbit putusan kasasi dari Mahkamah Agung maka kedua belah pihak sepakat untuk mengesampingkan putusan tersebut.

- Bahwa pada tanggal 16 Agustus 1995 telah terbit Akte Permohonan Pencabutan Kasasi dari ahli waris PoK yang dikirim ke Mahkamah Agung pada tanggal 28 Agustus 1995, namun pada tanggal yang sama yaitu pada tanggal 28 Agustus 1995 terbit Putusan Kasasi dari Mahkamah Agung nomor : XX, tanggal 28 Agustus 1995 yang isi putusannya mengabulkan gugatan dari ahli waris PoK untuk seluruhnya. Terhadap putusan tersebut ahli waris PoK mengabaikan perjanjian/perdamaian dengan mengajukan permohonan penetapan eksekusi ke PN Pati pada tanggal 25 Juni 2014 sehingga terbit Penetapan Eksekusi dari PN Pati nomor: 3/Pen.Anm.Eks/2014/PN Pti, tanggal 03 Juli 2014, namun sampai saat ini eksekusi tersebut belum dilaksanakan, sehingga sertifikat HM nomor 735 tersebut masih tercatat a.n. LWD dan Ch. Atas dasar putusan Kasasi dari Mahkamah Agung dan Penetap Eksekusi dari PN Pati tersebut K bin SS selaku ahli waris dari PoK menguasai sebagian dari objek tanah tersebut sejak kurun waktu bulan Juli 2014 dan pada tanggal 10 Juli 2015, K bin SS menyewakan sebagaian objek tanah tersebut seluas kurang lebih $6520 \mathrm{M}^{2}$ kepada S untuk selama 3 (tiga) tahun sejak bulan Juli 2015 s/d bulan Juli 2018, dengan biaya sewa sebanyak Rp. 13.000.000,(tiga belas juta rupiah).

- Dengan adanya putusan Kasasi dari Mahkamah Agung dan Penetap Eksekusi dari PN Pati tersebut, pada tanggal 13 Juli 2017 mengajukan gugatan perlawanan eksekusi/verzet sehingga terbit putusan PN Pati nomor : XXX. Tanggal 09 November 2017, yang isinya Perlawanan pelawan $\mathrm{Ch}$ tidak dapat diterima. Terhadap putusan tersebut $\mathrm{Ch}$ mengajukan banding sehingga terbit putusan banding dari Pengadilan Tinggi Jawa Tengah dengan nomor : XXX. Tanggal 10 April 2018, dengan isi putusan menyatakan putusan Mahkaman Agung nomor 3450 K/Pdt/1993, tanggal 28 Agustus 1995 tidak dapat dieksekusi (non eksekutable) karena telah terjadi perdamaian dan ada pencabutan gugatan tersebut, menyatakan Penetapan 


\begin{tabular}{llrr}
\hline \hline Volume: & 3 & E-ISSN: & $2655-1942$ \\
Number: & 1 & Terbitan: & Mei 2020 \\
Page : & $84-98$ & & \\
\hline
\end{tabular}

Eksekusi nomor : XXX, tidak sah dan tidak mempunyai kekuatan hukum tetap sehingga penetapan tersebut dicabut/dibatalkan. Terhadap putusan tersebut pihak $\mathrm{K}$ bin SS mengajukan kasasi, sehingga terbit putusan kasasi dari Mahkamah Agung dengan nomor : XXX, tanggal 30 November 2018, yang isi putusannya menolak permohonan kasasi dari $\mathrm{K}$ bin SS.

\section{Pertanyaan dan Analisa}

Berdasarkan penjelasan kasus di atas muncul beberapa pertanyaan yang menjadi permasalahan:

\section{Apa pengertian gugatan perdata, dan bagaimana proses pengajuannya sampai gugatan tersebut berkekuatan hukum tetap?}

Gugatan merupakan suatu perkara yang mengandung sengketa atau konflik antara pihakpihak yang menuntut pemutusan dan penyelesaian pengadilan. Menurut Sudikno Mertokusumo gugatan adalah tuntutan hak yaitu tindakan yang bertujuan memberikan perlindungan yang diberikan oleh pengadilan untuk mencegah perbuatan main hakim sendiri (eigenrichting).

Ciri-ciri gugatan (contentious) diantaranya adalah:

1. Masalah yang diajukan adalah penuntutan suatu hak atas sengketa antara seseorang atau badan hukum dengan seseorang atau badan hukum yang lain.

2. Adanya suatu sengketa dalam gugatan ini.

3. Terdapat lawan atau pihak lain yang bisa ikut diseret dalam gugatan ini.

4. Para pihak disebut penggugat dan tergugat.

Rangkaian Proses Gugatan Perdata:

1. Setelah gugatan didaftarkan di Pengadilan Negeri setempat, maka pada hari sidang pertama dan seterusnya:

a. Sidang dinyatakan dibuka dan terbuka untuk umum;

b. Para pihak (penggugat dan tergugat) diperintahkan memasuki ruang sidang; 


$\begin{array}{llrr}\text { Volume: } & 3 & \text { E-ISSN: } & 2655-1942 \\ \text { Number: } & 1 & \text { Terbitan: } & \text { Mei } 2020 \\ \text { Page : } & 84-98 & & \end{array}$

c. Para pihak diperiksa identitasnya (surat kuasanya), demikian pula diperiksa surat ijin praktik dari organisasi advokat;

d. Apabila kedua belah pihak lengkap maka diberi kesempatan untuk menyelesaikan dengan perkara secara damai;

e. Ditawarkan apakah akan menggunakan mediator dari lingkungan PN atau dari luar (lihat PERMA RI No.1 Tahun 2008);

f. Apabila tidak tercapai kesepakatan damai maka sidang dilanjutkan dengan pembacaan surat gugat oleh penggugat/kuasanya;

g. Apabila perdamaian berhasil maka dibacakan dalam persidangan dalam bentuk akta perdamaian yang bertitel DEMI KEADILAN BERDASARKAN KETUHANAN YME;

h. Apabila tidak ada perubahan acara selanjutnya jawaban dari tergugat; (jawaban berisi eksepsi, bantahan, permohonan putusan provisionil, gugatan rekonvensi);

i. Apabila ada gugatan rekonvensi tergugat juga berposisi sebagai penggugat rekonvensi;

j. Replik dari penggugat, apabila digugat rekonvensi maka ia berkedudukan sebagai tergugat rekonvensi;

k. Pada saat surat menyurat (jawab jinawab) ada kemungkinan ada gugatan intervensi (voeging, vrijwaring, toesenkomst);

1. Sebelum pembuktian ada kemungkinan muncul putusan sela (putusan provisionil, putusan tentang dikabulkan nya eksepsi absolut, atau ada gugat intervensi);

m. Pembuktian

n. Dimulai dari penggugat berupa surat bukti dan saksi;

o. Dilanjutkan dari tergugat berupa surat bukti dan saksi;

p. Apabila menyangkut tanah dilakukan pemeriksaan setempat;

q. Kesimpulan

r. Musyawarah oleh Majelis Hakim (bersifat rahasia);

s. Pembacaan Putusan;

t. Isi putusan:

- Gugatan dikabulkan,

- Gugatan ditolak,

- Gugatan tidak dapat diterima;

u. Atas putusan ini para pihak diberitahu hak-haknya apakah akan menerima, pikir-pikir atau akan banding. Apabila pikir-pikir maka diberi waktu selama 14 hari; 
Law, Development \& Justice Review

\begin{tabular}{llrr}
\hline \hline Volume: & 3 & E-ISSN: & 2655-1942 \\
Number: & 1 & Terbitan: & Mei 2020 \\
Page : & $84-98$ & & \\
\hline
\end{tabular}

v. Dalam hal ada pihak yang tidak hadir maka diberitahu terlebih dahulu dan dalam waktu 14 hari setelah pemberitahuan diberi hak untuk menentukan sikap. Apabila waktu 14 hari tidak menentukan sikap maka dianggap menerima putusan.

w. Ketika para pihak telah menerima putusan maka dikatakan putusan itu telah mempunyai kekuatan hukum yang tetap. Putusan perdata dikatakan memiliki kekuatan hukum tetap (inkracht van gewijsde) adalah putusan pengadilan tingkat pertama yang tidak diajukan banding, putusan banding yang tidak diajukan kasasi, dan putusan kasasi.

\section{Berdasarkan fakta perbuatan yang dilakukan oleh $\mathrm{K}$ bin SS, jelaskan apa dasar hukumnya?}

Perbuatan yang dilakukan saudara K SS, dalam bentuk.... meminta penetapan eksekusi kepada PN Pati dapat dipahami sebagai tindakan membatalkan perjanjian perdamaian (yang secara suka rela, berdasarkan Asas Kesepakatan (meeting of mind or intention) dibuat oleh para pihak), secara sepihak. Tindakan tersebut adalah tindakan yang apabila ditinjau dari Aspek Hukum Perdata (formil maupun materiil, khususnya Hukum Perjanjian ) sebagai tindakan yang tidak dapat dibenarkan dan tidak ada dasar hukumnya, dengan pertimbangan :

a. Bahwa pada tanggal 13 Agustus 1995 para pihak sepakat mengadakan perdamaian sebagaimana Surat Perjanjian tertanggal 13 Agustus 1995 yang dikuatkan dengan Akta Perdamaian nomor 51 tanggal 23 Agustus 1995 yang dibuat oleh Notaris IS.

b. Ditinjau dari Hukum perjanjian (Buku III KUH Perdata), Perdamaian adalah sebuah perjanjian ( Pasal 1851 KUH Perdata) yang tunduk pada Pasal 1320 KUH Perdata tentang Syarat Sah Perjanjian (yang isinya, kesepakatan, kecakapan, hal tertentu dan kausa halal/yang diperbolehkan).....dilihat dari ketentuan ini maka Perjanjian perdamaian yang ditindak lanjuti dengan dibuatnya Akte perdamaian secara Notarial adalah sah dan mengikat para pihak yang membuatnya.

c. Pasal $1338 \mathrm{KUH}$ Perdata salah satu isinya tentang Asas Pacta Sun Servanda (Kesepakatan yang sah, (telah sesuai dengan Pasal 1320 KUH Perdata) mengikat sebagai undang-undang bagi para pihak yang membuatnya)

d. Masih di Pasal 1338 KUH Perdata ....kesepakatan yang mengikat sebagai undang-undang tersebut... tidak dapat dibatalkan secara sepihak.....ini berarti untuk melakukan pembatalan perjanjian harus berdasarkan kesepakatan dari para pihak, dan dengan disertai alasan-alasan yang dibenarkan oleh hukum.

e. Menurut Keputusan MA nomor 454/K/Pdt/1991, sebuah Akte Perdamaian dapat dibatalkan ...Jika Isinya bertentangan engan undang-undang. Menurut saya Akte Perdamaian yang 
Law, Development \& Justice Review

$\begin{array}{llrr}\text { Volume: } & 3 & \text { E-ISSN: } & 2655-1942 \\ \text { Number: } & 1 & \text { Terbitan: } & \text { Mei } 2020 \\ \text { Page : } & 84-98 & & \end{array}$

dibuat para pihak isinya tidak melanggar undang-undang, sehingga tidak ada alasan untuk membatalkannya.

f. Bahwa terhadap kasus yang terjadi di antara para pihak, tidak sekedar telah dibuat Perjanjian Perdamaian pada tanggal 13 Agustus 1995 oleh para pihak yang dikuatkan dengan Akta Perdamaian nomor 51 tanggal 23 Agustus 1995 yang dibuat oleh Notaris IS., bahkan telah ditindaklanjuti dengan dibuatnya Akte Permohonan Pencabutan Kasasi dari ahli waris PK pada tanggal 16 Agustus 1995 yang dikirim ke Mahkamah Agung pada tanggal 28 Agustus 1995.

g. Pasal 1338 KUH Perdata, di dalamnya juga mencantumkan Asas Itikad Baik (...Perjanjian harus dilaksanakan dengan itikad baik). Dalam perkembangannya penerapan Asas Itikad Baik ini tidak hanya diterapkan pada waktu pelaksanaan perjanjian saja akan tetapi juga pada tahap sebelum perjanjian ditandatangani (pra kontrak), dan tahap pelaksanaan (kontrak) dan sesudah pelaksanaan (post kontrak).Terkait dengan hal ini saya berpendapat "bahwa saudara K SS tidak mempunyai itikad baik untuk melaksanakan isi perjanjian, sebagai upaya untuk mengakhiri sengketa yang timbul di antara para pihak."

h. Telah dipahami kaidah umum bahwa "Hukum melindungi Pihak-Pihak yang beritikad baik", oleh karena itu tindakan yang dilakukan oleh saudara KSS tidak mendapat perlindungan hukum, karena tidak didasari oleh Asas Itikad baik, artinya tindakan tersebut tidak mempunyai kekuatan hukum.

i. Berdasarkan pertimbangan di atas saya sepakat dengan Putusan Hakim tingkat banding dari Pengadilan Tinggi Jawa Tengah dengan nomor : 24/Pdt/2018/PT SMG. Tanggal 10 April 2018, dengan isi putusan menyatakan putusan Mahkaman Agung nomor $3450 \mathrm{~K} / \mathrm{Pdt} / 1993$, tanggal 28 Agustus 1995 tidak dapat dieksekusi (non eksekutable) karena telah terjadi perdamaian dan ada pencabutan gugatan tersebut, menyatakan Penetapan Eksekusi nomor : 3/Pen.Anm.Eks/2014/PN Pti, tidak sah dan tidak mempunyai kekuatan hukum tetap sehingga penetapan tersebut dicabut/dibatalkan. Terhadap putusan tersebut pihak saudara KSS mengajukan kasasi, sehingga terbit putusan kasasi dari Mahkamah Agung dengan nomor : $2923 \mathrm{~K} / \mathrm{Pdt} / 2018$, tanggal 30 November 2018, yang isi putusannya menolak permohonan kasasi dari saudara KSS

3. Sebelum adanya putusan Kasasi dari Mahkamah Agung nomor : 3450 K/Pdt/1993, tanggal 28 Agustus 1995 dan Penetapan Eksekusi dari PN Pati nomor : 3/Pen.Anm.Eks/2014/PN Pti, tanggal 03 Juli 2014, telah ada perdamian dan permohonan kasasi tersebut telah dicabut oleh pemohon kasasi. Dengan adanya hal tersebut apakah putusan Kasasi dari Mahkamah Agung nomor : 3450 K/Pdt/1993, tanggal 28 Agustus 1995 tetap berlaku atau tidak dan apakah dasar hukumnya ? Jelaskan! 


\begin{tabular}{llrr} 
Volume: & 3 & E-ISSN: & $2655-1942$ \\
Number: & 1 & Terbitan: & Mei 2020 \\
Page : & $84-98$ & & \\
\hline
\end{tabular}

Berdasarkan argumentasi yang telah saya paparkan di atas dan berdasarkan pada Keputusan Majelis Hakim tingkat Banding Jawa Tengah nomor : 24/Pdt/2018/PT SMG. Tanggal 10 April 2018, dengan isi putusan menyatakan putusan Mahkaman Agung nomor 3450 K/Pdt/1993, tanggal 28 Agustus 1995 tidak dapat dieksekusi (non eksekutable) karena telah terjadi perdamaian dan ada pencabutan gugatan tersebut, maka Putusan Mahkamah Agung nomor 3450 K/Pdt/1993, tanggal 28 Agustus 1995, meskipun itu sah akan tetapi tidak dapat dilaksanakan/ tidak dapat dieksekusi (non eksekutable) karena telah terjadi perdamaian dan ada pencabutan gugatan tersebut.

4. Dengan adanya Putusan Kasasi dari Mahkamah Agung nomor : 3450 K/Pdt/1993, tanggal 28 Agustus 1995 dan Penetapan Eksekusi dari PN Pati nomor : 3/Pen.Anm.Eks/2014/PN Pti, tanggal 03 Juli 2014 tersebut, apakah K SS mempunyai hak atas sebagian tanah HM No. 735 Ds. Bumirejo Kec. Margorejo Kab. Pati, meskipun belum dilaksanakan eksekusi dan apakah dasar hukumnya ? Jelaskan!

Bahwa isi Putusan Banding dari Pengadilan Tinggi Jawa Tengah dengan nomor: 24/Pdt/2018/PT SMG. Tanggal 10 April 2018, adalah

menyatakan putusan Mahkaman Agung nomor 3450 K/Pdt/1993, tanggal 28 Agustus 1995 tidak dapat dieksekusi (non eksekutable) karena telah terjadi perdamaian dan ada pencabutan gugatan tersebut.

$>$ menyatakan Penetapan Eksekusi nomor : 3/Pen.Anm.Eks/2014/PN Pti, tidak sah dan tidak mempunyai kekuatan hukum tetap sehingga penetapan tersebut dicabut/dibatalkan.

Bahwa atas putusan banding tersebut, saudara K SS telah mengajukan kasasi, sehingga terbit putusan kasasi dari Mahkamah Agung dengan nomor : 2923 K/Pdt/2018, tanggal 30 November 2018, yang isi putusannya menolak permohonan kasasi dari saudara K SS. Berdasarkan fakta di atas saya berpendapat bahwa saudara K SS TIDAK BERHAK hak atas sebagian tanah HM No. 735 Ds. Bumirejo Kec. Margorejo Kab. Pati 


\begin{tabular}{llrr} 
Volume: & 3 & E-ISSN: & $2655-1942$ \\
Number: & 1 & Terbitan: & Mei 2020 \\
Page : & $84-98$ & & \\
\hline
\end{tabular}

5. Pada saat K SS menguasai dan menyewakan sebagian tanah HM No. 735 Ds. Bumirejo Kec. Margorejo Kab. Pati tersebut, siapakah yang mempunyai hak atas tanah HM No. 735 Ds. Bumirejo Kec. Margorejo Kab. Pati tersebut dan apakah dasar hukumnya ? Jelaskan!

Mengacu pada jawaban saya terhadap pertanyaan no 10 di atas dapat ditarik kesimpulan :

a. bahwa saudara K SS, tidak berhak atas sebagian tanah HM No. 735 Ds. Bumirejo Kec. Margorejo Kab. Pati.

b. Mengacu pada huruf a di atas, maka saudara K SS, tidak mempunyai Alas Hak (title) untuk menyewakan tanah tersebut kepada siapapun.

c. Tindakan saudara K SS tersebut di atas dapat digugat dengan dasar Perbuatan Melawan Hukum, oleh pihak yang berhak.

d. Akibat hukum terhadap perjanjian yang dibuat oleh pihak yang tidak berhak maka perjanjian itu batal demi hukum, minimal dapat dibatalkan,

e. Apabila penyewa beritikad baik (tidak tahu jika saudara K SS bukanlah orang yang berhak untuk menyewakan) maka dia dilindungi undang-undang.

6. Dalam perkara ini telah ada Putusan Kasasi dari Mahkamah Agung nomor : 3450 K/Pdt/1993, tanggal 28 Agustus 1995 dan Penetapan Eksekusi dari PN Pati nomor : 3/Pen.Anm.Eks/2014/PN Pti, tanggal 03 Juli 2014 namun belum dilaksanakan eksekusi. Akan tetapi sebelum adanya putusan kasasi dan penetapan eksekusi tersebut telah ada perdamian dari kedua belah pihak dan dalam perdamaian tersebut terdapat kesepakatan bahwa apabila dikemudian hari terbit putusan kasasi dari Mahkamah Agung, maka kedua belah pihak akan mengesampingkan putusan tersebut. Dengan adanya hal tersebut manakah yang harus dilaksanakan oleh para pihak dan apakah dasar hukumnya ? Jelaskan ! 


\begin{tabular}{llrr}
\hline \hline Volume: & 3 & E-ISSN: & 2655-1942 \\
Number: & 1 & Terbitan: & Mei 2020 \\
Page : & $84-98$ & & \\
\hline
\end{tabular}

Menurut pendapat saya bahwa berdasarkan prinsip-prinsip yang berlaku dalam hukum perjanjian sebagai mana telah saya jelaskan di atas, maka para pihak harus tetap melaksanakan isi perjanjian perdamaian yang telah dibuat para pihak tersebut.

7. Apakah perbuatan yang dilakukan oleh K SS dengan menguasai dan menyewakan sebagian tanah HM No. 735 Ds. Bumirejo Kec. Margorejo Kab. Pati, setelah adanya Putusan Kasasi dari Mahkamah Agung nomor : 3450 K/Pdt/1993, tanggal 28 Agustus 1995 dan Penetapan Eksekusi dari PN Pati nomor : 3/Pen.Anm.Eks/2014/PN Pti, tanggal 03 Juli 2014 namun belum dilaksanakan eksekusi tersebut, merupakan perbuatan melawan hukum dan apakah dasar hukumnya ? Jelaskan !

Ya, sebenarnya atas perbuatan K SS itu dapat dikenakan dua dasar gugatan karena telah terjadi apa yang disebut Pembarengan Gugatan (samenloop), yaitu pembarengan antara gugatan karena wanprestasi dan gugatan karena perbuatan melawan hukum, dengan rincian :

a. karena wanprestasi :

Prinsip Pacta Sun Servanda, mendasari Perjanjian Perdamaian yang dibuat oleh para pihak mengikat sebagai undang-undang, terlebih lagi dengan dibuatnya Akte Perdamaian secara Notariil. Perjanjian Perdamaian tersebut hanya dapat dibatalkan jika disepakati oleh para pihak (Pasal 1338 KUH Perdata) atau karena isinya bertentangan dengan undang-undang (Keputusan MA nomor 454/K/Pdt/1991), jadi tindakan saudara K SS telah melanggar isi perjanjian (wanprestasi)

b. karena Perbuatan Melawan/melanggar Hukum :

Perbuatan saudara K SS telah memenuhi isi ketentuan Pasal 1365 KUH Perdata tiap perbuatan melanggar, yang membawa kerugian pada seorang lain, mewajibkan orang yang karena salahnya menerbitkan kerugian itu, mengganti kerugian tersebut.

c. Secara sederhana dirumuskan : 


$\begin{array}{llrr}\text { Volume: } & 3 & \text { E-ISSN: } & 2655-1942 \\ \text { Number: } & 1 & \text { Terbitan: } & \text { Mei } 2020 \\ \text { Page : } & 84-98 & & \end{array}$

jika kerugian timbul karena perjanjian maka dasar gugatan nya adalah wanprestasi, akan tetapi jika kerugian yang ditimbulkan bukan karena perjanjian maka dasar gugatan nya adalah perbuatan melawan/melanggar hukum.

$>$ Atas gugatan wanprestasi hanya dapat menuntut kerugian materiil saja, akan tetapi tuntutan karena perbuatan melawan/melanggar hukum, dapat berupa kerugian materiil dan immaterial.

\section{Bisakah saudara jelaskan apakah pengertian perkara perdata telah memiliki kekuatan hukum yang tetap dan apakah perkara ini telah memiliki kekuatan hukum tetap dan apakah dasar hukumnya ? Jelaskan !}

$>$ Sebuah perkara perdata dikatakan telah mempunyai kekuatan hukum yang tetap, apabila atas putusan atas perkara tersebut (PN, PT, MA) tidak dapat lagi dilakukan upaya hukum biasa (misalnya banding untuk putusan PN, Kasasi untuk putusan PT, dan Putusan MA, atau perlawanan), atau ada upaya hukum biasa akan tetapi batas waktu untuk melakukan hal itu telah terlampaui .

Terhadap Putusan yang telah memiliki kekuatan hukum tetap (in Kracht van Gewijsde) dapat dilakukan upaya hukum luar biasa berupa peninjauan kembali (request civil) dan perlawanan oleh pihak ketiga.

Ya... sejak terbitnya Putusan Kasasi Mahkamah Agung dengan nomor : 2923 K/Pdt/2018, tanggal 30 November 2018, yang isi putusannya menolak permohonan kasasi dari KSS, atas/terhadap :

Putusan Banding dari Pengadilan Tinggi Jawa Tengah dengan nomor : 24/Pdt/2018/PT SMG. Tanggal 10 April 2018, yang isinya adalah

- menyatakan putusan Mahkaman Agung nomor $3450 \mathrm{~K} / \mathrm{Pdt} / 1993$, tanggal 28 Agustus 1995 tidak dapat dieksekusi (non eksekutable) karena telah terjadi perdamaian dan ditindaklanjuti dengan pencabutan gugatan tersebut. 


\begin{tabular}{llrr}
\hline \hline Volume: & 3 & E-ISSN: & $2655-1942$ \\
Number: & 1 & Terbitan: & Mei 2020 \\
Page : & $84-98$ & & \\
\hline
\end{tabular}

- menyatakan Penetapan Eksekusi nomor : 3/Pen.Anm.Eks/2014/PN Pti, tidak sah dan tidak mempunyai kekuatan hukum tetap sehingga penetapan tersebut dicabut/dibatalkan.

\section{Adakah upaya hukum lain setelah adanya putusan kasasi Mahkamah Agung atas Verzet/perlawanan dalam perkara perdata dan apakah dasar hukumnya ? Jelaskan !}

Ada, ...Ketika sebuah putusan pengadilan (MA) telah menjadi berkekuatan hukum tetap (in Kracht van Gewijsde), maka upaya hukum yang memungkinkan untuk dilakukan dalam perkara ini adalah peninjuan kembali (request civil) dasar hukum Pasal 67 Undang-undang no. 14 tahun 1985 tentang Mahkamah Agung, yang telah diubah dengan undang-undang no. 5 tahun 2004 (perubahan pertama) dan undang-undang no. 3 tahun 2009 (perubahan kedua)

\section{Bagaimana pendapat saudara tentang perkara ini apabila dikaitkan dengan Peraturan Mahkamah Agung nomor 1 tahun 1956 dan bisakah saudara jelaskan dasar hukumnya ? Jelaskan !}

Yang saya pahami dari pendapat beberapa ahli, Perma no. 1 tahun 1956 tidak terkait dengan tugas kepolisian, tetapi itu lebih dipahami sebagai aturan intern bagi para hakim yang sedang memeriksa perkara pidana yang atas objeknya (tanah) juga sedang disidangkan secara perdata.

Untuk lebih jelasnya saya kutip :... Pasal 1 Perma 1/1956 tersebut dinyatakan: "Apabila pemeriksaan perkara pidana harus diputuskan hal adanya suatu hal perdata atas suatu barang atau tentang suatu hubungan hukum antara dua pihak tertentu, maka pemeriksaan perkara pidana dapat dipertangguhkan untuk menunggu suatu putusan Pengadilan dalam pemeriksaan perkara perdata tentang adanya atau tidak adanya hak perdata itu." 


\begin{tabular}{llrr} 
Volume: & 3 & E-ISSN: & $2655-1942$ \\
Number: & 1 & Terbitan: & Mei 2020 \\
Page : & $84-98$ & & \\
\hline
\end{tabular}

Penundaan perkara pidana tersebut di atas juga dapat didasarkan pada yurisprudensi MA, putusan No. 628 K/Pid/1984. Dalam putusan ini, MA memerintahkan Pengadilan Tinggi Bandung untuk menunggu adanya putusan pengadilan yang berkekuatan hukum tetap, yang memutuskan mengenai status kepemilikan tanah.

11. Bisakah saudara jelaskan siapakah pemegang hak atas tanah HM No. 735 Ds. Bumirejo Kec. Margorejo Kab. Pati sejak terbitnya sertipikat HM No. 735 Ds. Bumirejo Kec. Margorejo Kab. Pati sampai dengan adanya putusan kasasi Mahkamah Agung atas verzet/perlawanan yang diajukan dan apakah dasar hukumnya ? Jelaskan !

Menurut pendapat saya berdasarkan uraian saya pada pertanyan-pertanyaan sebelumnya, maka pemegang hak atas tanah HM No. 735 Ds. Bumirejo Kec. Margorejo Kab. Pati seluas 13.280 M² adalah saudara LWD dan Ch.

12. Terlepas dari isi putusan Putusan Banding dari Pengadilan Tinggi Jawa Tengah dengan nomor : 24/Pdt/2018/PT SMG. Tanggal 10 April 2018 dan isi putusan kasasi dari Mahkamah Agung dengan nomor : 2923 K/Pdt/2018, tanggal 30 November 2018 tersebut, apakah diperbolehkan K SS SURI menguasai dan menyewakan sebagian tanah HM No. 735 Ds. Bumirejo Kec. Margorejo Kab. Pati, atas dasar adanya Putusan Kasasi dari Mahkamah Agung nomor : 3450 K/Pdt/1993, tanggal 28 Agustus 1995 dan Penetapan Eksekusi dari PN Pati nomor : 3/Pen.Anm.Eks/2014/PN Pti, tanggal 03 Juli 2014, meskipun belum dilaksanakan eksekusi dan apakah dasar hukumnya ? Jelaskan!

Menurut pendapat saya, Terlepas dari isi putusan Putusan Banding dari Pengadilan Tinggi Jawa Tengah dengan nomor : 24/Pdt/2018/PT SMG. Tanggal 10 April 2018 dan isi putusan kasasi dari Mahkamah Agung dengan nomor : 2923 K/Pdt/2018, tanggal 30 November 2018, .......saudara KLIWON bin SAPUAN SURI tetap tidak berhak melakukan tindakan tersebut, dengan alasan bahwa : 


$\begin{array}{llrr}\text { Volume: } & 3 & \text { E-ISSN: } & 2655-1942 \\ \text { Number: } & 1 & \text { Terbitan: } & \text { Mei } 2020 \\ \text { Page : } & 84-98 & & \end{array}$

a. pada tanggal 13 Agustus 1995 para pihak sepakat mengadakan perdamaian sebagaimana Surat Perjanjian tertanggal 13 Agustus 1995 yang dikuatkan dengan Akta Perdamaian nomor 51 tanggal 23 Agustus 1995 yang dibuat oleh Notaris IMAM SUTARYO, S.H.

b. Ditinjau dari Hukum perjanjian (Buku III KUH Perdata), Perdamaian adalah sebuah perjanjian ( Pasal 1851 KUH Perdata) yang tunduk pada Pasal 1320 KUH Perdata tentang Syarat Sah Perjanjian (yang isinya, kesepakatan, kecakapan, hal tertentu dan kausa halal/yang diperbolehkan).....dilihat dari ketentuan ini maka Perjanjian perdamaian yang ditindak lanjuti dengan dibuatnya Akte perdamaian secara Notariil adalah sah dan mengikat para pihak yang membuatnya.

c. Pasal 1338 KUH Perdata salah satu isinya tentang Asas Pacta Sun Servanda (Kesepakatan yang sah, (telah sesuai dengan Pasal 1320 KUH Perdata) mengikat sebagai undang-undang bagi para pihak yang membuatnya)

d. Masih di Pasal 1338 KUH Perdata ....kesepakatan yang mengikat sebagai undangundang tersebut.... tidak dapat dibatalkan secara sepihak.....ini berarti untuk melakukan pembatalan perjanjian harus berdasarkan kesepakatan dari para pihak, dan dengan disertai alasan-alasan yang dibenarkan oleh hukum, sehingga Perjanjian Perdamaian tersebut tetap ada (exis) mengikat dan mempunyai kekuatan pembuktian .

e. Menurut Keputusan MA nomor 454/K/Pdt/1991, sebuah Akte Perdamaian dapat dibatalkan ...Jika Isinya bertentangan dengan undang-undang. Menurut saya Akte Perdamaian yang dibuat para pihak isinya tidak melanggar undang-undang, sehingga tidak ada alasan untuk membatalkannya.

\section{Terkait jawaban nomor 7 tersebut, apakah yang dimaksud dengan kerugian materiil dan kerugian imateriil serta apakah perbuatan K SS tersebut merupakan kategori perbuatan melawan hukum dan dapat dilakukan gugatan materiil dan imateriil serta dapat dilakukan proses hukum pidana ?} Jelaskan !

a. Kerugian materiil, merupakan kerugian yang timbul karena wanprestasi, artinya kerugian itu timbul karena debitor tidak melaksanakan kewajibannya. Komponen kerugian karena wanprestasi adalah costen : biaya, scaden : rugi, interessen : bunga/keuntungan yang tidak jadi diperoleh. 


$\begin{array}{llrr}\text { Volume: } & 3 & \text { E-ISSN: } & 2655-1942 \\ \text { Number: } & 1 & \text { Terbitan: } & \text { Mei } 2020 \\ \text { Page : } & 84-98 & & \end{array}$

b. Kerugian immaterial, adalah kerugian yang lazim timbul dari gugatan perbuatan melawan/melanggar hukum. Kerugian immaterial ini pada dasarnya sulit dinilai dengan uang. Dasar timbulnya gugatan immaterial, misalnya pencemaran nama baik, hilangnya waktu, pikiran dan tenaga karena berurusan dengan perkara yang dijalaninya, pandangan masyarakat terhadap penggugat akibat munculnya kasus tersebut.

c. Sebelumnya, Perlu dipahami saya ini “ diparingi” sedikit ilmu oleh Allah terkait hukum perdata, khususnya hukum perjanjian dan perbuatan melawan hukum, yang secara umum disebut hukum perikatan. Perbedaan antara hukum perdata dan hukum pidana antara lain jika terjadi pelanggaran, kerugian akibat pelanggaran terhadap hukum perdata/hukum perjanjian dituntut dengan dasar wanprestasi, atau jika kerugian timbul bukan karena perjanjian maka dasar gugatanya adalah perbuatan melawan hukum. Ujung-ujungnya gugatan atas wanprestasi dan atau perbuatan melawan hukum adalah GANTI RUGI....bukan perampasan kemerdekaan.

d. Secara teori hukum (baik teori hukum perjanjian maupun teori tentang perbuatan melawan hukum, tindakan/perbuatan saudara K SS telah dapat dikualifikasikan sebagai perbuatan wanprestasi dan atau perbuatan melawan hukum.

Saya tidak paham tentang teori hukum pidana, termasuk menetapkan apakah tindakan/perbuatan saudara K SS dapat dipidana. 